\title{
PENERAPAN INTELEGENSIA BUATAN DENGAN ALGORITMA NEGAMAX PADA APLIKASI PERMAINAN DERET LIMA
}

\author{
${ }^{1}$ Ridwanto Salmon Aruan, ${ }^{2}$ Heti Mulyani \\ Sekolah Tinggi Teknologi Indonesia, Jurusan Teknik Informatika \\ e-mail : $\underline{{ }^{1} \text { rasalmon26@gmail.com }}$
}

\begin{abstract}
ABSTRAK
Perkembangan teknologi semakin pesat, termasuk perkembangan didunia hiburan digital dalam hal ini perkembangan permainan berbasis komputer. intelegensia buatan adalah merupakan bagian dari kemajuan teknologi itu sendiri yang membuat mesin atau komputer dapat melakukan pekerjaan seperti dan sebaik manusia dimana komputer dapat berfikir selayaknya manusia, dalam dunia permainan komputer pun demikian, komputer dapat berpikir selayaknya manusia dalam melakukan permainan.

Permainan deret lima yang menerapkan perkembangan teknologi permainan digital berbasis komputer dengan menggunakan Intelegensia buatan dengan algoritma negamax membentuk komputer dapat bermain, berpikir selayaknya manusia dalam menyusun bola berderet sebanyak lima buah secara horizontal, vertikal, maupun diagonal dimana komputer dapat mengalahkan manuasi dalam bermain.
\end{abstract}

Permainan deret lima merupakan tipe permainan simetris, yang menggunakan papan berpetak dalam permaianannya. Pemain akan menyusun bola berwarna putih dan hitam sebanyak lima buah secara berderet baik horizontal, vertikal, maupun diagonal di papan permaianan. Pemain yang terlebih dahulu dapat menyusun bola itu yang memenangkan permainan.

Kata Kunci : Intelegensi Buatan, Algoritma Negamax

\section{PENDAHULUAN}

Perkembangan teknologi di era globalisasi saat ini semakin pesat dan sangat dibutuhkan hampir di semua bidang dimana semua orang dapat terhubung dengan mudah, cepat, dan efisien, sehingga semakin menuntut setiap masyarakat dunia untuk mengikuti perkembangan teknologi. Atas kemajuan teknologi komputer ini pun banyak membantu manusia dalam bekerja bahkan kemampuan teknologi komputer dapat menyaingi kemampuan manusia itu sendiri.

Kecerdasan/intelegensia buatan adalah merupakan bagian dari kemajuan teknologi itu sendiri yang membuat mesin atau komputer dapat melakukan pekerjaan seperti dan sebaik manusia dimana komputer dapat 
berfikir selayaknya manusia. Kecerdasan/intelegensia buatan dapat diterapkan dalam berbagai bidang seperti Sistem Pakar (Expert System), Pengolahan Bahasa Alami (Natural Language Processing), Pengenalan Ucapan (Speech Recognition), Robotika dan Sistem Sensor, Computer vision, serta yang paling menarik adalah penerapannya dalam permainan (game).

Pembuatan aplikasi kecerdasan/intelegensia buatan dalam bidang permainan sangat berguna bagi manusia tidak hanya sekedar hiburan dalam mengisi waktu luang, namun dapat juga membantu manusia untuk mengasah kecerdasan, meningkatkan kreatifitasi, dan belajar mengelola emosi. Sehinga pengguna dari aplikasi permainan tidak hanya pada kalangan anak-anak saja, tapi kalangan dewasa juga. Aplikasi permainan pun sangat pesat dan memiliki pasar sendiri di dunia industri, sebut saja pokemon go dan Clash of Clans yang sempat ramai di masyaratkat.

Ada banyak aplikasi permainan di buat dengan prinsip intelensi buatan atau Artificial Intellegence (AI) dari game yang sederhana sampai yang rumit. Dalam pembuatan aplikasi permainan dengan prinsip intelengesia buatan digunakan berbagai macam algoritma pemrograman diantaranya minimax, negamax, dan alpha-beta. Pengembangan game itu sendiri masih banyak dikembangkan oleh para peneliti, programmer, maupun ilmuwan dengan memanfaatkan penggunaan algortitma pemrograman tersebut.

Dari penelitian yang sudah ada maka penulis tertarik untuk melakukan pengembangan intelegensia buatan dalam sebuah permainan sederhana dengan pemanfaat algoritma negamax dengan judul "Penerapan Intelegensia Buatan Dengan Algoritma Negamax Pada Aplikasi Permainan Deret Lima”.

\section{KAJIAN PUSTAKA}

a. Intelegensia Buatan

Intelegensia buatan atau yang juga disebut kecerdasan buatan yang dalam bahasa inggrisnya Artificial Intellegence (AI) merupakan bagaian dari kemajuan perkembangan teknologi komputer yang sangat membantu manusia dalam melakukan aktifitasnya, dimana mesin (komputer) dapat melakukan aktifitas, berfikir selayaknya manusia. Kecerdasan buatan menurut Paul Y. Gloess, adalah ilmu yang mempelajari bagaimana suatu mesin seolah-olah memiliki kecerdasan dalam memecahkan suatu masalah yang diberikan kepadanya.

Beberapa definis intelegensia buatan $(A I)$ menurut para ahli diantaranya:

1. Schalkoff (1990). AI adalah bidang studi yang berusaha menerangkan dan meniru perilaku cerdas dalam bentuk proses komputasi.Rich dan Knight (1991). AI adalah studi tentang cara membuat komputer melakukan sesuatu yang, sampai saat ini, orang dapat melakukannya lebih baik. 
2. Luger dan Stubblefield (1993). AI adalah cabang ilmu komputer yang berhunbungan dengan otomasi perilaku yang cerdas.

3. Haag dan Keen (1996). AI adalah bidang studi yang berhubungan dengan penangkapan, pemodelan, dan penyimpanan kecerdasan manusia dalam sebuah sistem teknologi informasi sehingga sistem tersebut dapat memfasilitasi proses pengambilan keputusan yang biasanya dilakukan oleh manusia.

b. Pengertian Algoritma

Abu Ja'far Muhammad Ibnu Musa Al-Kwarizmi, penulis buku "Aljabar wal muqabala" pada abad ke-9 dianggap sebagai pencetus pertama Algoritma karena di dalam buku tersebut beliau menjelaskan langkah langkah dalam menyelesaikan berbagai persoalan aritmatika (aljabar), kemungkinan besar kata "Algoritma" yang kemungkinan berubah menjadi "Algorism" selanjutnya menjadi "Algorithm".

Ada beberapa definisi tentang algoritma menurut para ahli, diantaranya sebagai berikut:

1. Teknik penyusunan langkah-langkah penyelesaian masalah dalam bentuk kalimat dengan jumlah kata terbatas, tetapi tersusun secara logis dan sisitematis.

2. Suatu prosedur yang jelas untuk menyelesaikan suatu persoalan dengan mengunakan langkah-langkah tertentu dan terbatas jumlahnya.

3. Algoritma adalah deretan langkah-langkah komputasi yang mentransformasikan data masukan menjadi keluaran.

4. Algoritma adalah deretan yang menjelaskan untuk memecahkan masalah, yaitu untuk memperoleh keluaran yang diinginkan dari suatu masukan dalam jumlah waktu yang terbatas.

5. Algoritma adalah prosedur komputasi yang terdefinisi dengan baik yang menggunkan beberapa nilai sebagai masukan dan menghasilkan beberapa nilai yang disebut keluaran.

Menurut Donald E. Knuth dalam bukunya yang berjudul The Art of compter programming [KNU73], algoritma harus memiliki lima ciri penting sebagai berikut:

1. Algoritma harus berhenti setelah mengerjakan sejumlah langkah terbatas.

2. Setiap langkah harus didefiniskan dengan tepat dan tidak berarti-dua (ambiguous).

3. Algoritma memiliki nol atau lebih masukan (input). Masukan ialah besarab yang diberikan algoritma untuk di proses.

4. Algoritma memliki nol atau lebih keluaran (output). Keluaran dapat berupa pesan tau besaran yang memiliki hubungan dengan masukan.

5. Algoritma harus sangkil (effective). Setiap langkah harus sederhana sehingga dapat dikerjakan dalam jumlah waktu yang masuk akal. 


\section{c. Algoritma Negamax}

Algoritma Negamax merupakan bentuk varian dari algoritma minimax yang bergantung pada zero-sum game (permainan kompetisi).Perbedaan dari algoritma negamax dan minimax adalah negamax hanya menggunakan fungsi maksimal dan tidak seperti algoritma minimax yang menggunakan kedua fungsi yaitu fungsi maksimal dan fungsi minimal. Ini dapat dilakukan dengan menegasikan nilai yang dikembalikan dari point lawan daripada mencari nilai minimal, sehingga dapat dikatakan negamax adalah penyederhanaan implementasiminimax. Hal ini dapat ditunjukan dengan menggunakan relasi matematika berikut:

$$
\operatorname{Max}(\mathbf{a}, \mathbf{b})==-\operatorname{Min}(-\mathbf{a},-\mathbf{b})
$$

Kelebihan negamax dibanding algoritma adversial serach yang lain adalah algoritma negamax lebih sederhana dan hasil optimal oleh karena itu negamax dipandang dapat menghasilkan solusi yang optimal yang dapatdiimplementasikan pada pemain komputer dalam permainan deret lima.

\section{d. Permainan Deret Lima}

Permainan yang terbentuk dari kata dasar 'main' yaitu melakukan permainan untuk menyenangkan hati (dengan menggunakan alat-alat tertentu atau tidak). Sedang kan Permainan atau Gim merupakan sebuah aktivitas rekreasi dengan tujuan bersenang-senang, mengisi waktu luang, atau berolahraga ringan. Permainan biasanya dilakukan sendiri atau bersama-sama (kelompok).

Ide dasar dari permainan deret lima ini yaitu permainan Tac-Tic-Toc, atau yang dikenal di Indonesia catur jawa yang biasa dimainkan oleh anakanak, dimana teknik permainannya pemain harus membuat garis tanpa putus secara vertikal, horizontal maupun diagonal dengan batu ataupun daun sebanyak tiga buah. Sedangkan pada permainan deret lima ini pemain akan menyusun batu sebanyak lima buah di dalam papan permainan berskala $15 \mathrm{X}$ 15 secara verikal, horizontal, maupun diagonal, pemain yang pertama kali menyusun deratan sebanyak lima buah dia yang menjadi pememang. Berikut teknik permainannya:

1. Pemilihan objek yang digunakan dalam permainan menggunakan bola berwarna yang harus disuse sebanyak 5 buah secara berederatan baik secara horizontal, vetikal, maupun diagonal di papan berskala 15 X 15 .

2. Pemain bebas meletakan bola dimana saja atau bebas menajalankan strateginya.

3. Permainan dimainkan oleh dua pemain yang dimainkan secara bergantian.

4. Penyusunan bola harus tersusun sejajar membentuk garis lurus tanpa putus.

5. Setiap pemain akan di berikan waktu sebanyak 15 detik untuk berpikir, menyusun bola maupun menghambat lawan dalam menyusun bola.

6. Apabila waktu yang berikan sudah habis namun pemain juga tidak melakukan pemainan maka pihak lawan yang menang.

7. Permainan akan berakhir apabila salah satu pemain telah menysusun bola berderet sebanyak 5 buah, dan papan permainan sudah penuh (permainan seri). 


\section{e. $\quad$ Pengertian UML (Unified Modelling Language)}

UML ( Unified Modelling Language) adalah salah satu alat bantu yang sangat handal di dunia pengembangan system yang berorientasi obyek. Hal ini disebabkan karena UML menyedikan Bahasa pemodelan visual yang memungkinkan bagi pengembang system untuk membuat cetak biru atas visi mereka dalam bentuk yang baku, mudah dimengerti serta dilengkapi dengan mekanisme yang efektif untuk berbagi (sharing) dan mengkomunikasikan rangcangan mereka dengan yang lain.

UML merupakan kesatuan dari bahas pemodelan yang dikembangkan oleh Booch, Object Modelling Technique (OMT) dan Object Oriented Software Engineering (OOSE). Dengan UML, metode Booch, OMT, OOSE digabungkan dengan membuang elemen-elemen yang tidak praktis ditambah dengan elemen-elemen dari metode lain yang lebih efektif dan elemen-elemen baru yang belum ada pada metode terdahulu sehingga UML lebih ekspresif dan seragam daripada metode lainnya.

\section{f. $\quad$ Konsep Dasar OOP (Object Oriented Programming)}

OOP (Object Oriented Programming) atau pemrograman berorientasi objek adalah suatu cara baru dalam berpikir serta berlogika dalam menghadapi masalh-masalah yang akan dicoba-atasi dengan bantuan komputer. OOP tidak seperti pendahulunya (pemrograman terstruktur), mencoba melihat permasalahan lewat pengamatan dunia nyatadimana setiap objek adalah entitas tunggal yang memiliki kombinasi struktur data dan fungsi tertentu. Ini kontras dengan pemrograman terstruktur dimana struktur data dan fungsi didefinisikan secara terpisah dan tidak berhubungan secara erat.

Pada perkembangannya, filosopi OOP menciptaka sinergi yang luar biasa sepanjang siklus pengembangan perangkat lunak (perencanaan, analisis, perancangan, implementasi serta pengujian) sehingga dapat diterapkan pada perancangan sistem secara umum, menyangkut perangkat lunka, perangkat keras, serta sistem informasi secara keseluruhan.

\section{METODOLOGI PENELITIAN}

a. Metodologi Pengumpulan Data 
Metode pengumpulan data yang digunakan dalam pembuatan laporan Skripsi adalah :

1. Studi Pustaka

Studi pustaka dilakukan dengan cara-cara mempelajari teori-teori, bukubuku, dan sumber-sumber lain yang berhubungan dengan objek permasalahan yang dibahas.

2. Observasi

Observasi melakukan pengamatan langsung terhadap objek yang diteliti untuk mendapatkan data dan informasi yang diperlukan sesuai dengan permasalahan.

b. Metode Pengembangan Sistem

Dalam pelaksanaannya proses tugas akhir perlu dilakukan pengembangan sistem, perancangan ini membutuhkan sebuah metodologi sebagai pedoman bagaimana dan apa yang harus dilakukan selama mengembangkan sistem. Metode pengembangan sistem yang digunakan adalah Metode Spiral. Model spiral adalah proses perangkat lunak yang evolusioner yang merangkai sifat iteratif dari prototipe dengan cara kontrol dan aspek sistematis dari model skuensial linier. Model yang awalnya diusulkan oleh Boehm ini memiliki potensi untuk pengembangan pertambahan perangkat lunak secara cepat. Tahapan-tahapan kegiatannya adalah sebaga berikut :

1. Komunikasi pelangan : Tugas- tugas yang dibutuhkan untuk membangun komunikasi yang efektif diantara pengembang dan pelanggan.

2. Perancanaan : Tugas-tugas yang dibutuhkan untuk mendefinisikan sumber-sumber daya, ketepatan waktu, dan proyek informasi lain yang berhubungan.

3. Analisis resiko : Tugas-tugas yang dibutuhkan untuk menafsirkan resiko-resiko, baik majemen maupun teknis.

4. Perekayasaan : Tugas-tugas yang dibutukan unutk membangun satu atau lebih reprensentasi dari aplikasi tersebut.

5. Konstruksi dan peluncuran : Tugas-tugas yang dibutuhkan untuk mengkonstruksi, menguji, memasang (instal) dan memberikan pelayanan kepada pemakai (contohnya pelatihan dan dokumentasi).

6. Evaluasi pelanggan: Tugas-tugas yang dibutuhkan unutk memperoleh umpan balik dari pelanggan dengan didasarkan pada evaluasi representasi perangkat lunak, yang dibuat selama masa perekayasaan, dan implementasi selama masa pemasangan.

\section{HASIL DAN PEMBAHASAN}

a. Analisis Permainan Yang Akan Dibangun 
Permainan yang akan dibangun yaitu permainan ber-genre strategi dengan karakter bola hitam dan putih yang mewakili masing-masing pemain, setiap pemain diberi kesempatan waktu untuk bermain menentukan strategi meletakkan bola dan bebas meletak bola dimana saja di daerah papan permainan yang berskala $15 \times 15$ untuk menyusun deret maupun menghambat jalannya lawan dalam menyusun bola.

Permainan strategi menyusun bola berderet sebanyak lima buah ini diharapkan dapat meningkatkan kreatifitas, melatih mental dan emosi, meningkatkan daya analisa maupun hiburan bagi pemainnya.

b. Analisa Penggunaan Algoritma Negamax

Algoritma Negamax digunakan untuk melakukan perkiraan langkah berikutnya. Fungsi ini digunakan oleh prosedur gerakan komputer. Algoritma negamax hanya menggunakan fungsi maksimal dan tidak seperti algoritma minimax yang menggunakan kedua fungsi yaitu fungsi maksimal dan fungsi minimal. Ini dapat dilakukan dengan menegasikan nilai yang dikembalikan dari point lawan daripada mencari nilai minimal, sehingga dapat dikatakan negamax adalah penyederhanaan implementasiminimax. Kelebihan negamax dibanding algoritma adversial serach yang lain adalah algoritma negamax lebih sederhana dan hasil optimal oleh karena itu negamax dipandang dapat menghasilkan solusi yang optimal yang dapatdiimplementasikan pada pemain komputer dalam permainan deret lima. Beberapa alasan penulis menggunakan algoritma negamax, antara lain:

1. Algoritma negamax banyak digunakan pada aplikasi permainan simetris.

2. Operasi logika dan aritmatka sederhana dan tidak terlalu banyak.

Dengan alasan diatas maka penulis menggunakan algoritma negamax untuk membangun aplikasi permainan deret lima untuk menentukan langkah yang akan dilakukan oleh komputer.

c. Perancangan Use Case Diagram

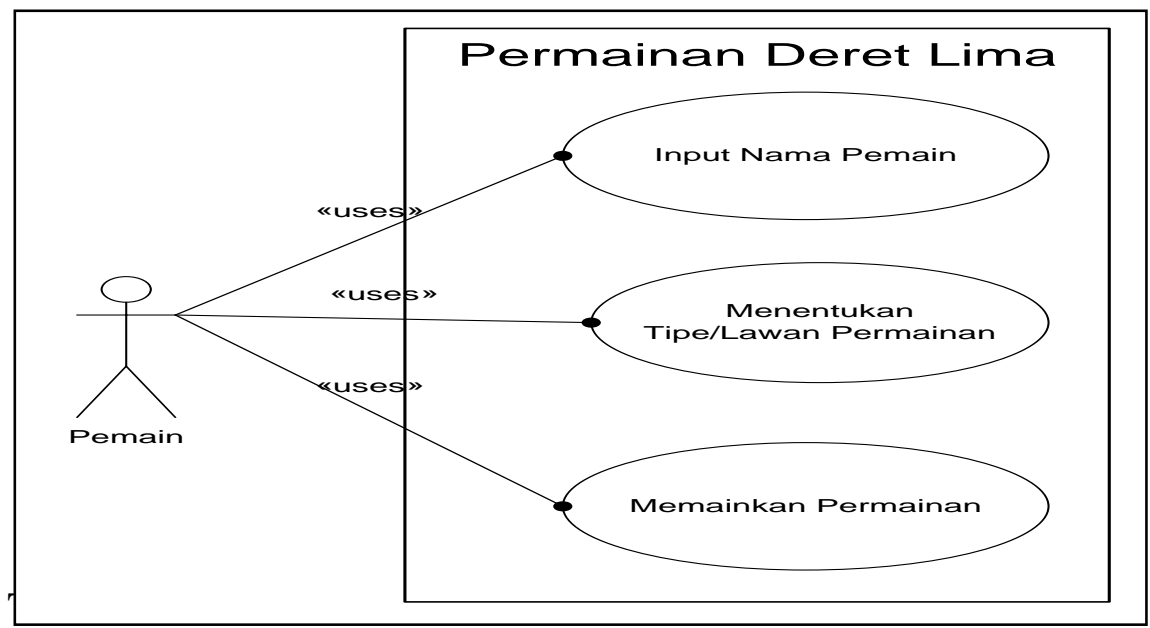




\begin{tabular}{|l|l|l|}
\hline NO & USE CASE & \multicolumn{1}{|c|}{ KETERANGAN } \\
\hline 1 & $\begin{array}{l}\text { Input Nama } \\
\text { Pemain }\end{array}$ & $\begin{array}{l}\text { Proses dimana actor menginputkan } \\
\text { namanya. }\end{array}$ \\
\hline 2 & $\begin{array}{l}\text { Menentukan } \\
\text { Tipe/Lawan } \\
\text { Permainan }\end{array}$ & $\begin{array}{l}\text { Proses dimana actor menentukan tipe } \\
\text { permainan yaitu Manusia lawan komputer, } \\
\text { manusia lawan manusia, dan komputer } \\
\text { lawan komputer. Pada tipe manusia lawan } \\
\text { komputer pemain dapat menentukan yang } \\
\text { pertama kali memulai permainan. }\end{array}$ \\
\hline 3 & $\begin{array}{l}\text { Memainkan } \\
\text { Permainan }\end{array}$ & $\begin{array}{l}\text { Proses memainkan permainan deret lima, } \\
\text { sesuai dengan tipe/lawan yang sudah } \\
\text { ditentukan. }\end{array}$ \\
\hline
\end{tabular}

\section{d. Activity Diagram}

Activity Diagram Input Nama Pemain

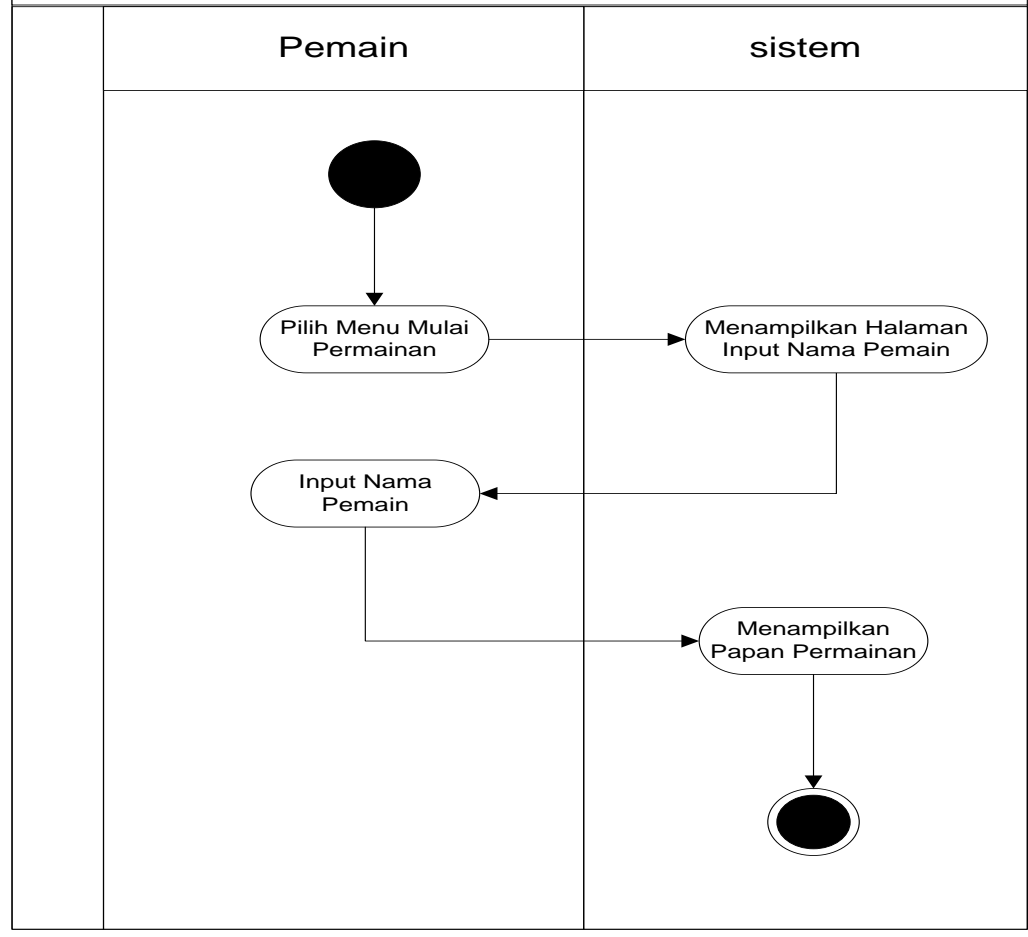

Gambar 3. Digram Aktifitas Input Nama Pemain

Dari diagram aktifitas diatas dapat dijelaskan bahwa ketika pemain memilih menu Mulai permainan, maka sistem akan menampilkan halaman 
untuk menginputkan nama pemain, setelah pemain mengunputkan namanya maka system akan menampilkan papan permainan.

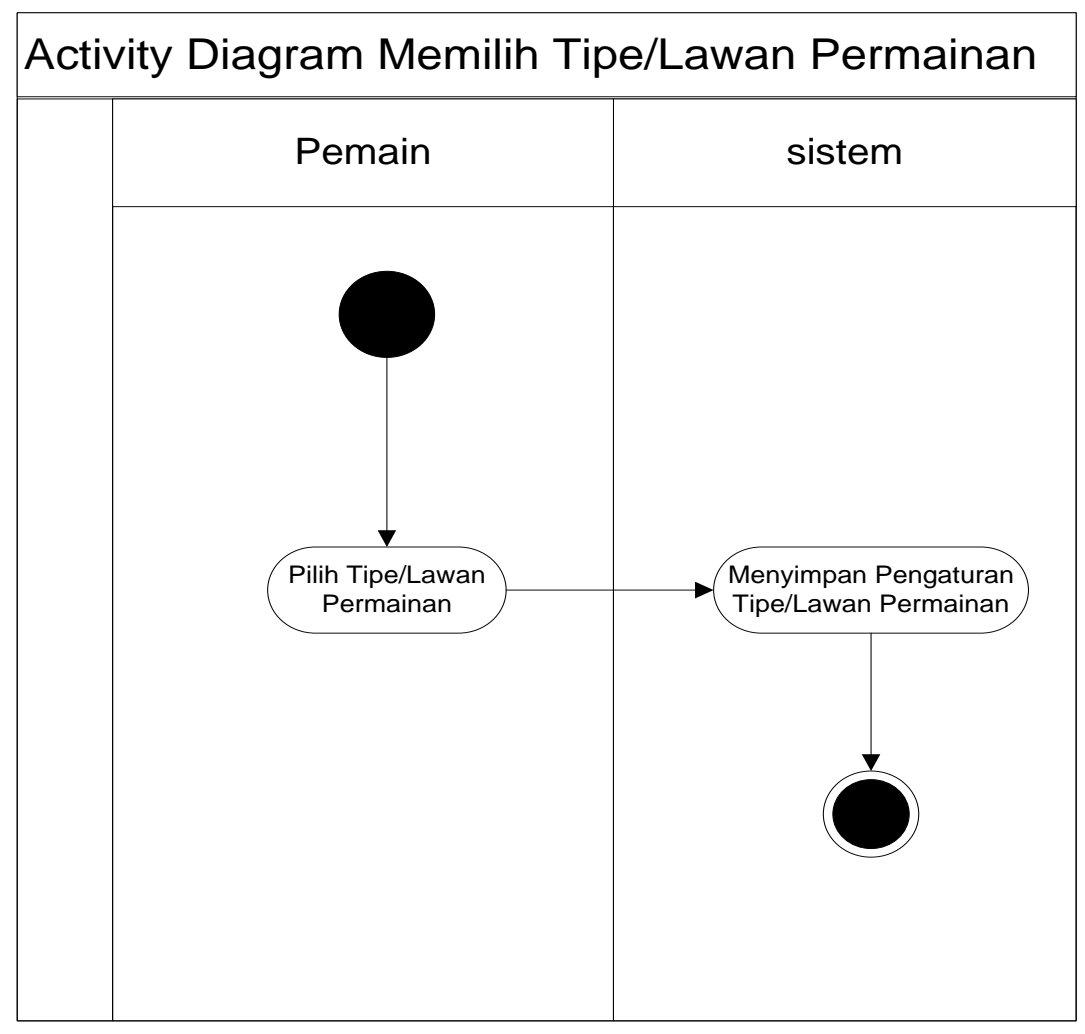

Gambar 4. Diagram Aktifitas Memilih Tipe/Lawan Permainan

Penjelasan diagram aktifitas diatas sebelum melakukan permainan pemain terlebih dahulu untuk memilih tipe/lawan dalam permainan, adapun tipe/lawan dalam permainan deret lima yaitu pemain/manusia melawan komputer pada tipe ini pemin dapat mengatur siap yang telebih dahulu melakukan permainan baik computer terlebih dahulu maupun pemain, manusia melawan manusia, dan komputer melawan komputer pada tipe ini komputer dapat memainkan permainan tanpa adanya perintah dari manusia.

e. Sequence Diagram 


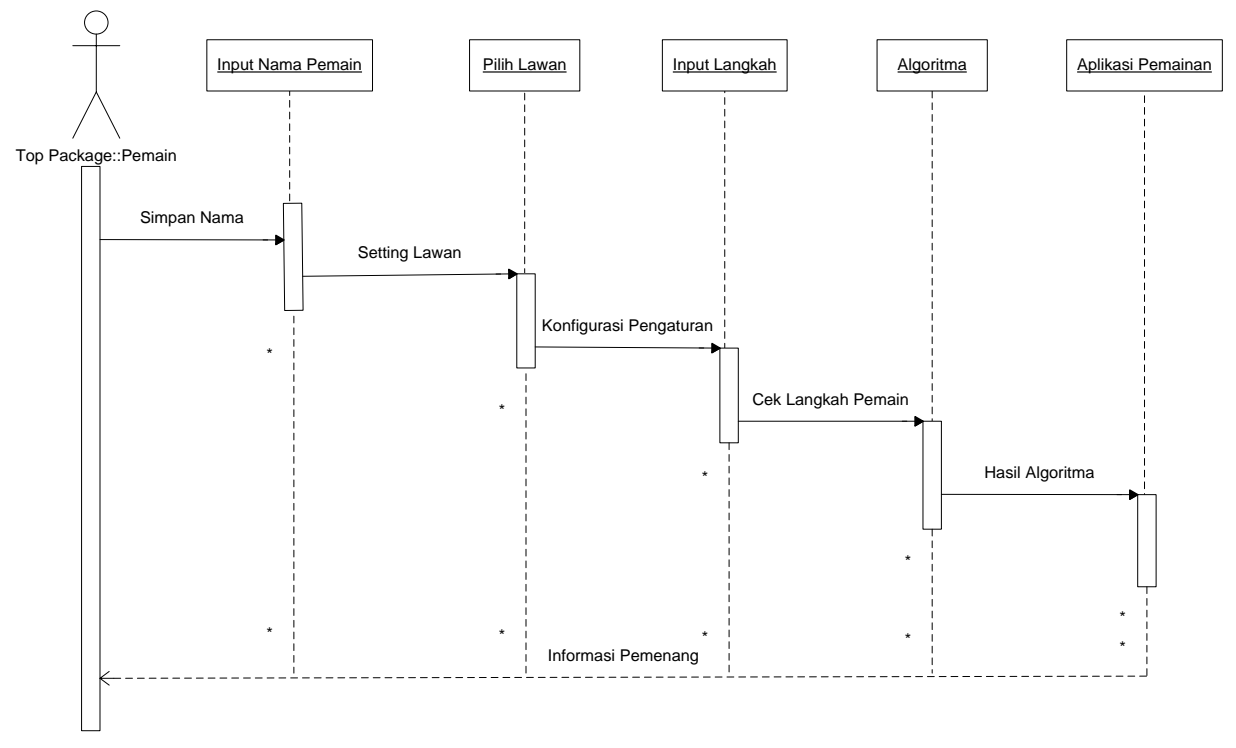

mengkonfigurasinya untuk dapat memulia permainan dengan menginput langkah guna membentuk deretan bola maupun menghadang langkah lawan. Inputan langkah yang dilakukan masing-masing tiap pemain akan di cek melalui algoritma yang digunakan apakah langkah-langkah tersebut sudah membentuk sebuh deretan garis lurus bola sebanyak lima buah. Dari pengecekan melalui algoritma maka sistem akan memberitahukan hasil perhitungan langkah dan memberikan informasi hasil akhir dari permainan siapa myang menjadi pemenang melalui kontak pesan yang muncul.

f. Class Diagram

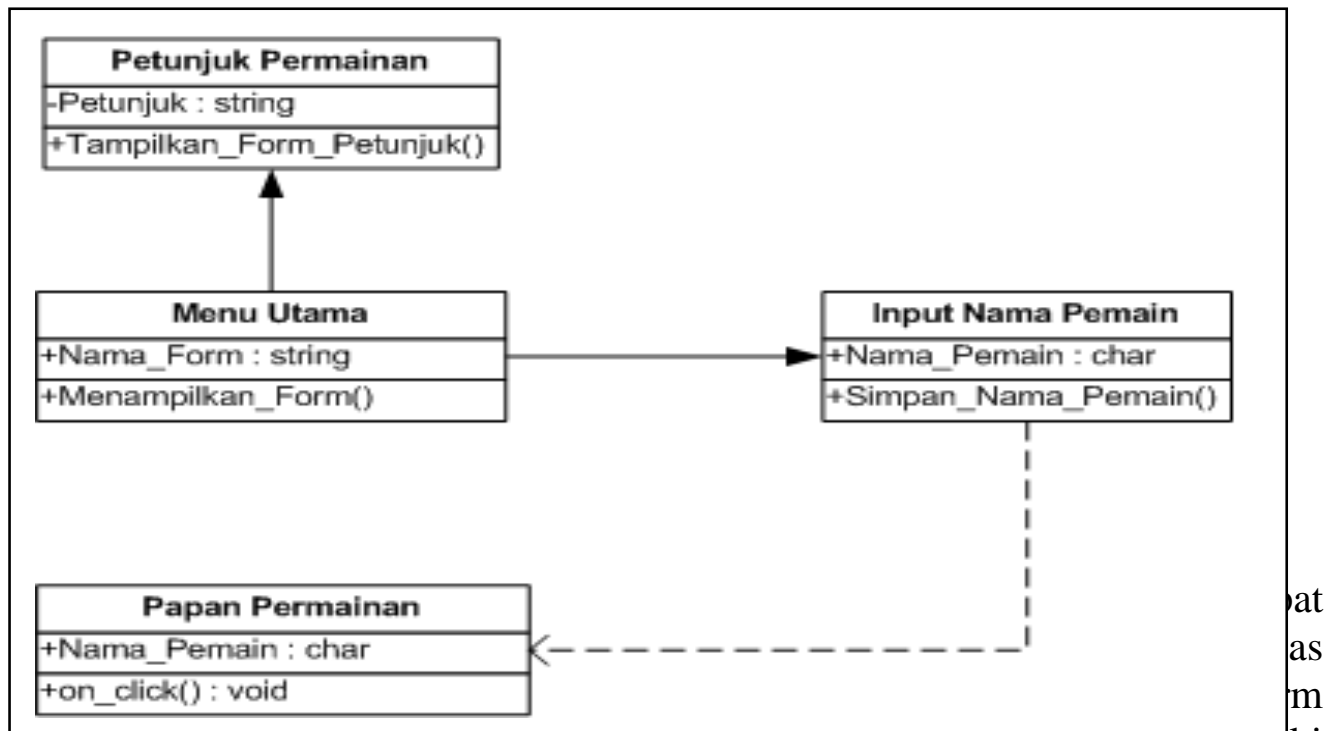

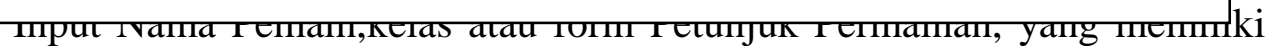
atribut dari nama form. Jenis visibility yang digunakan yaitu public yang ditandai dengan simbol '+', yang artinya semua kelas serta objek diluar 
kelasyang bersangkutan dapat menggunakan/mengakses atribut serta operasi yang dideklarasikan sebagai public.

\section{g. Flowchart Diagram}

Flowchart diagram menjelaskan siklus dari semua kegiatan computer mulai dari input (masukan) yakni berupa nama pemain, inputan langkah, proses algoritma untuk menghitung jumlah deretan bola yang disusun setiap pemain, sampai mendapatkan hasil output (keluaran) berupa informasi pemenang dalam permainan yakni nama pemain. Berikut dibawah ini flowchart diagram dalam permainan deret lima.

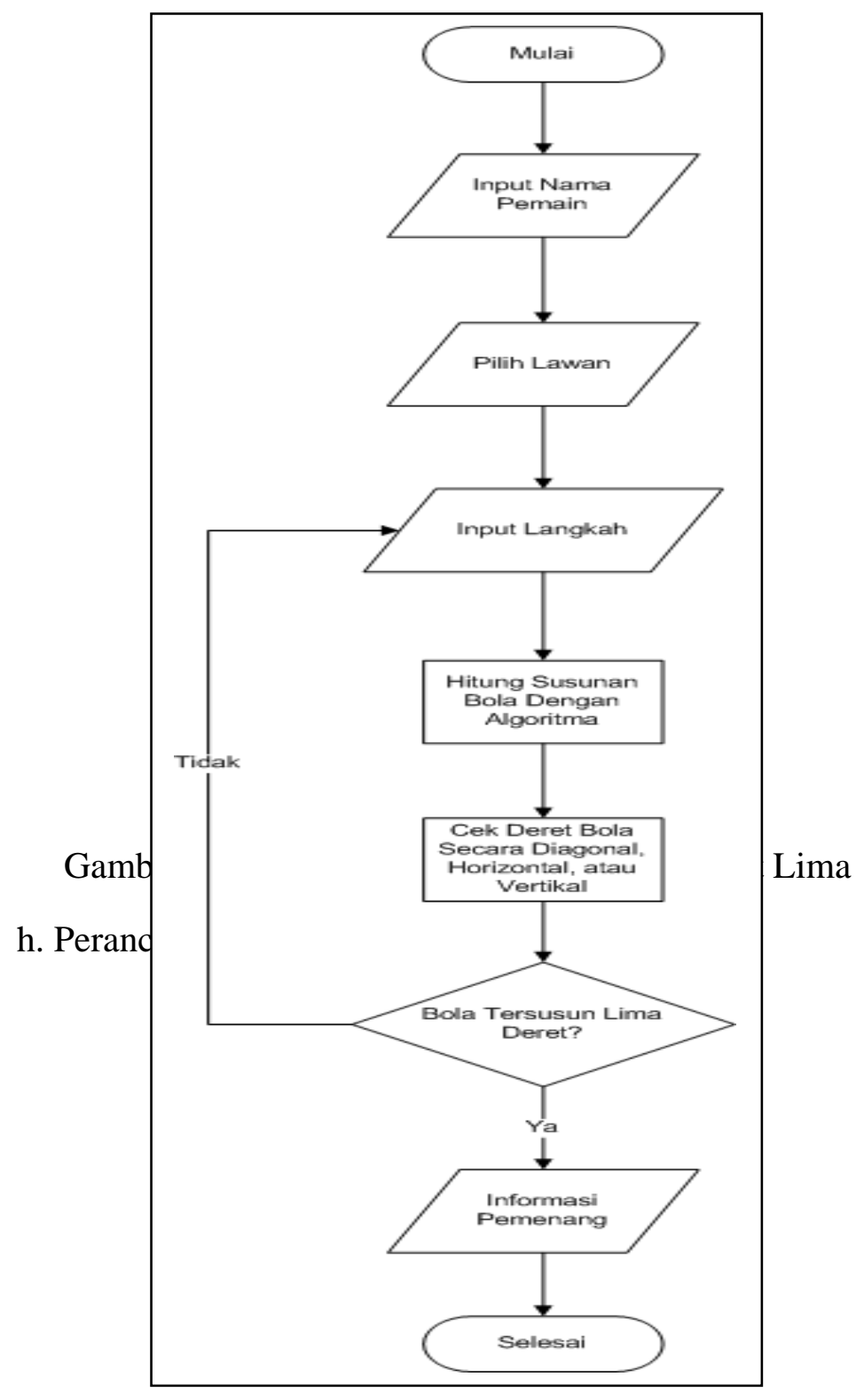




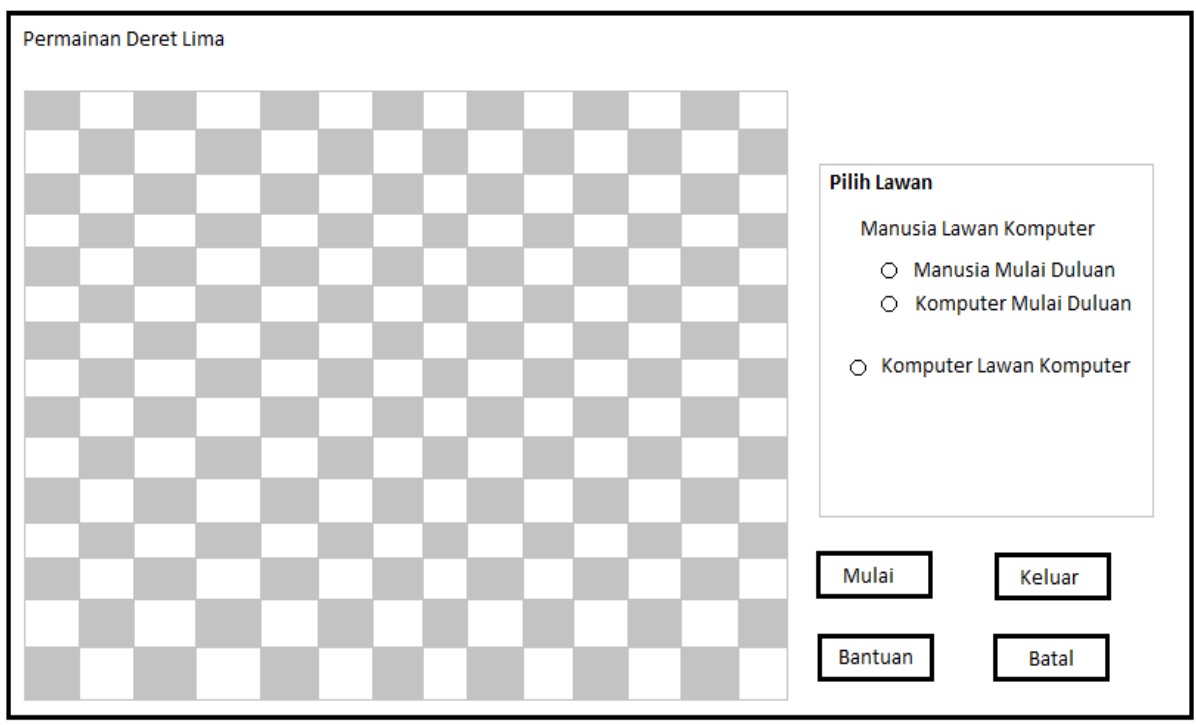

Gambar 7. Papan Permainan

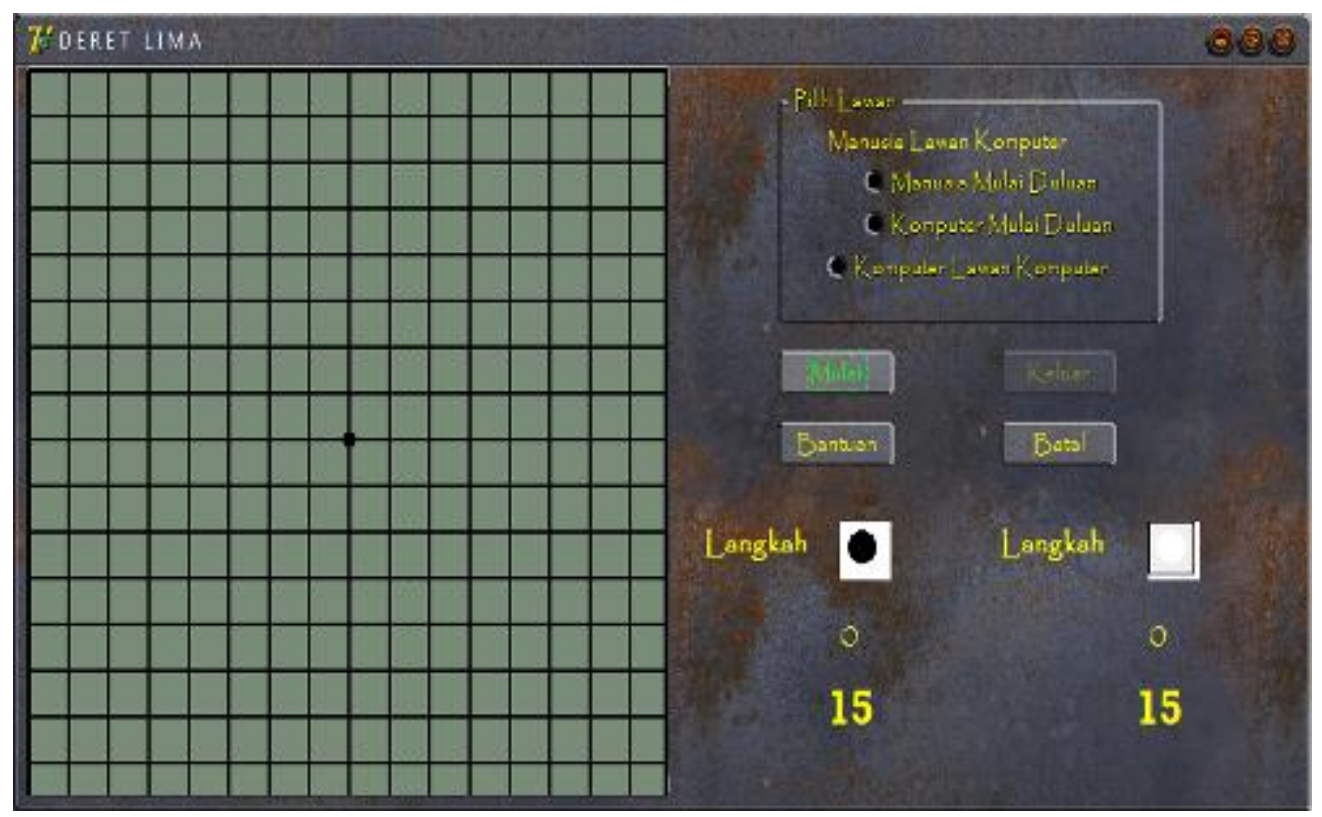

Gambar 8. Form Papan Permainan

\section{KESIMPULAN}

Dari hasil penelitian dan pengujian yang telah dilakukan oleh penulis terhadap aplikasi permainan deret lima maka dapat disimpulkan kelebihan dan kekurangan sebagai berikut:

Kelebihan:

1. Algoritma Negamax dapat diterapkan pada aplikasi permainan deret lima untuk menerapkan intelegensia buatan.

2. Aplikasi deret lima dibatasi waktu dalam permainannya yakni 15 detik.

3. Aplikasi permainan deret lima mampu dimainkan oleh computer lawan komputer 
4. Aplikasi permainan deret lima memiliki skala papan permainan $15 \mathrm{X}$ 15.

Kekurangan:

1. Pada aplikasi ini tidak menggunakan pengaturan tingkatan kesulitan.

2. Pada aplikasi ini tidak memakai sistem skoring permainan.

3. Pada permainan ini tidak dapat digunakan lebih dari 2(dua) pemain.

\section{DAFTAR PUSTAKA}

Andoyo, Andreas dan Suyono. Dasar Pemrograman Delphi, (Yogyakarta: Andi, 2016)

Kadir, Abdul \& Terra Ch. Triwahyuni, Pengenalan Teknologi Informasi, Yogyakarta: Andi, 2003

Kristanto, Andri. Kecerdasan Buatan, Yogyakarta: Graha Ilmu. 2004

Kusumadewi, S. Artificial Intelligence (Teknik dan Aplikasinya), Yogyakarta: Graha Ilmu, 2003

Maemudin, Dedy. Penerapan Algoritma Pencarian Solusi Minimax Dengan Alpha-Beta Pada Aplikasi Permainan Sederhana. Jakarta: Universitas Mercubuana, 2008

M.Sc, M.Math, Ph.D, Drs. Suarga, Algoritma Pemrograman. Yogyakarta: Andi, 2006

Munawar. Pemodelan Visual dengan UMl, Yogyakarta: Graha Ilmu, 2005

Munir, Rinaldi, Algoritma dan Pemrograman, Bandung: Informatika Bandung, 2006

Nugroho, Andi, Analisis Dan Perancangan Sistem Informasi Dengan

Metodologi Berorientasi Objek (Edisi Revisi), Bandung: Informatika

Bandung, 2004

Setiawan, Yudha C, Panduan Object-Oriented Programming (OOP) Dasar Pemrograman Delphi. Yogyakarta: Andi, 2004

S. Pressman, Ph. D , Roger. Rekayasa Perangkat Lunak. Yogyakarta: Andi, 2007 